ECONOMICS OF THE PUBLIC SECTOR 


\section{Economics of the Public Sector}

D.I. Trotman-Dickenson, PhD, MSc. (Econ.), B. Com.

Professor Emeritus, University of Glamorgan 
CC D.I. Trotman-Dickenson 1996

All rights reserved. No reproduction, copy or transmission of this publication may be made without written permission.

No paragraph of this publication may be reproduced, copied or transmitted save with written permission or in accordance with the provisions of the Copyright, Designs and Patents Act 1988, or under the terms of any licence permitting limited copying issued by the Copyright Licensing Agency, 90 Tottenham Court Road, London W1P 9HE.

Any person who does any unauthorised act in relation to this publication may be liable to criminal prosecution and civil claims for damages.

First published 1996 by MACMILLAN PRESS LTD

Houndmills, Basingstoke, Hampshire RG21 6XS

and London

Companies and representatives

throughout the world

ISBN 978-0-333-59669-2

ISBN 978-1-349-13264-5 (eBook)

DOI 10.1007/978-1-349-13264-5

A catalogue record for this book is available from the British Library.

$\begin{array}{rrrrrrrrrr}10 & 9 & 8 & 7 & 6 & 5 & 4 & 3 & 2 & 1 \\ 05 & 04 & 03 & 02 & 01 & 00 & 99 & 98 & 97 & 96\end{array}$


To

Caroline, Emma, Oliver and Thomas 


\section{Contents}

Acknowledgements $\quad$ xxi

Foreword xxii

\section{PART 1 THE ECONOMIC FRAMEWORK}

1 Economic Systems and Models 3

Political Economy 3

Types of Economic System 3

Shift from Marxist Principles to Market Forces 5

Economic Models $\quad 6$

The Sector Model of an Economy 6

Input-Output Model 9

Summary 15

Suggested Further Reading $\quad 15$

$\begin{array}{ll}\text { Exercises } & 17\end{array}$

2 National Income 18

Purposes of National Income Data $\quad 18$

Early Estimates of National Income $\quad 20$

Proposals for Reforming National Income Accounts 24

Definition and Calculation of National Income 27

Choice of Method of Calculating National Income for Developed
and Developing Countries

International Comparison of National Income 35

Complementary Indicators $\quad 39$

Comparison of the Standard of Living 43

Determination of National Income and the Multiplier 46

Fluctuations in National Income $\quad 50$

Trade Cycle Theories 53

Multiple Causes $\quad 55$

Forecasts $\quad 55$

Summary $\quad 57$

Suggested Further Reading $\quad 58$

Exercises $\quad 59$

3 Allocation of Resources and Provision of Public Goods 60

Optimum Allocation $\quad 60$

Utilitarian Approach to Economic Welfare 61 
Market Allocation of Resources and Government Intervention 62 Opportunity Cost in the Public and Private Sectors 62 Summary $\quad 65$

Suggested Further Reading $\quad 66$

$\begin{array}{ll}\text { Exercises } & 67\end{array}$

\section{PART 2 PUBLIC FINANCE: EXPENDITURE}

4 Public Expenditure $\quad 71$

$\begin{array}{ll}\text { Public Finance } & 71\end{array}$

$\begin{array}{ll}\text { Functions of the State } & 71\end{array}$

$\begin{array}{ll}\text { Definition of Public Expenditure } & 74\end{array}$

Theories of Public Expenditure $\quad 74$

Observations on the Growth of Public Expenditure $\quad 78$

Trends in Public Expenditure: Current and Constant Prices 78

Empirical Evidence on the International Growth of $\begin{array}{lr}\text { Public Expenditure } & 81\end{array}$

Reasons for the Growth of Public Expenditure $\quad 82$

Restraints to the Growth of Public Expenditure 86

Consequences of the Growth of Public Expenditure $\quad 87$

$\begin{array}{lr}\text { Summary } & 88\end{array}$

Suggested Further Reading $\quad$. $\quad 89$

$\begin{array}{lr}\text { Exercises } & 90\end{array}$

5 Public Expenditure in Practice: The British Experience 91

Phases in the Growth of Public Expenditure $\quad 91$

$\begin{array}{lr}\text { Development of Social Services } & 93\end{array}$

$\begin{array}{lr}\text { Education } & 93\end{array}$

Health Services $\quad 93$

Relief of the Poor $\quad 95$

Establishment of the Welfare State $\quad 96$

'From Welfare State to Welfare Society' 103

Changes in Administrative Structures:

Management and Provision of Public Services 104

$\begin{array}{ll}\text { The Citizen's Charter } & 106\end{array}$

$\begin{array}{ll}\text { Summary } & 107\end{array}$

$\begin{array}{ll}\text { Suggested Further Reading } & 108\end{array}$

$\begin{array}{ll}\text { Exercises } & 110\end{array}$

\section{PART 3 PUBLIC FINANCE: TAXATION}

6 The Theory of Taxation and the Tax System 113

The Need for Revenue 113

Early Taxes 113 
$\begin{array}{ll}\text { Theories of Taxation } & 115\end{array}$

Equality of Sacrifice, Rates of Taxation $\quad 118$

$\begin{array}{ll}\text { Rates of Taxation } & 120\end{array}$

Principles of Taxation $\quad 123$

A Tax System 125

Merits and Demerits of Direct and Indirect Taxation 126

$\begin{array}{ll}\text { Pattern of Taxation } & 130\end{array}$

Revenue Maximisation and 'Laffer Curve' Analysis 134

$\begin{array}{ll}\text { Summary } & 135\end{array}$

Suggested Further Reading $\quad 136$

$\begin{array}{ll}\text { Exercises } & 137\end{array}$

7 Taxes on Income 138

Basis of Income Tax 138

The Origin of Income Tax in the UK 139

Compliance of Income Tax with the Principles of Taxation 140

$\begin{array}{ll}\text { Income Tax and Incentives in Theory } & 148\end{array}$

Income Tax and Incentives in Practice 149

$\begin{array}{ll}\text { Supply of Labour and Taxation } & 150\end{array}$

Empirical Evidence on Tax Disincentives and the Supply of Labour

Effect of Progressive Income Tax on the Level of Personal Savings and the Pattern of Investment 158

Empirical Evidence on Effects of Taxation on Savings and Investment $\quad 160$

Inflation and Indexation for Income Tax Purposes 161

$\begin{array}{ll}\text { Recent Innovations } & 163\end{array}$

Negative Income Tax (NIT) 164

$\begin{array}{ll}\text { Summary } & 166\end{array}$

$\begin{array}{ll}\text { Suggested Further Reading } & 167\end{array}$

$\begin{array}{ll}\text { Exercises } & 168\end{array}$

8 Taxes on Profits 169

$\begin{array}{lr}\text { Early Taxes on Incomes of Businesses } & 169\end{array}$

$\begin{array}{ll}\text { Definition of Profit and Business } & 169\end{array}$

$\begin{array}{ll}\text { Computation of Profits } & 170\end{array}$

Illusory Profits, Inflation and Taxation 172

Profits Tax: Differentiated Rate on Distributed and
Undistributed Profits

Corporation Tax: The New System of Computation 174

The Effects of Profits Taxes 175

$\begin{array}{ll}\text { Taxation of Excess Profits } & 176\end{array}$

$\begin{array}{ll}\text { Tax on Profits from North Sea Oil } & 179\end{array}$

The Use of Government Revenue from North Sea Oil 183

$\begin{array}{ll}\text { Social Security Contributions as a Form of Taxation } & 184\end{array}$

The Surcharge - Departure from the Principles of Insurance 186

$\begin{array}{ll}\text { Corporate Taxation in Europe } & 188\end{array}$

$\begin{array}{ll}\text { Unitary Tax } & 190\end{array}$ 
Summary 191

Suggested Further Reading 193

Exercises 194

9 Taxes on Consumption 195

Types of Taxes 195

Choice of Goods to be Taxed 196

Tax Rates 198

Negative Indirect Taxation - Subsidies 200

Indirect Taxation in the UK 202

Energy and Environment Tax Measures 208

Impact of Developments in the European Community on
Indirect Taxation

Summary 211

Suggested Further Reading $\quad 212$

Exercises 213

10 Taxes on Capital 214

Definition of Capital 214

Types of Taxes on Capital 215

Revenue and Policy Aspects of Taxation of Capital 216

Capital Transfer Tax/Inheritance Tax 217

Capital Gains Tax $\quad 219$

Wealth Tax $\quad 220$

Valuation and Problems of Indexation 220

Effects of Inflation on the Value of Assets 222

Compliance of Capital Taxes with the Principles of Taxation 222

Trend Away from Taxes on Capital 225

Taxation of Capital in the UK $\cdot 225$

Stamp Duties 229

Capital Taxation in the European Community 229

Summary 231

Suggested Further Reading 232

Exercises 233

11 Reform of the Tax System, Expenditure Tax and the Meade Report; The European

Dimension $\quad 234$

Need for Reform 234

Idea of an Expenditure Tax 234

Outline of a Universal Expenditure Tax 235

Problems of Introducing the New System 236

Advantages of an Expenditure Tax 237

Modification of Taxation $\quad 238$

The European Dimension $\quad 239$

$\begin{array}{ll}\text { Summary } & 240\end{array}$ 
Suggested Further Reading $\quad 241$

$\begin{array}{ll}\text { Exercises } & 242\end{array}$

12 Taxable Capacity, Incidence of Taxation and the Tax Burden 243

Taxable Capacity Defined 243

Measurement of Taxable Capacity 243

Tax Burden of a Country 244

Taxpayers' Burden 245

Incidence of Taxation $\quad 245$

Incidence of Benefits 249

International Comparison of the Tax Burden 249

The Hidden Cost of Taxation: Compliance and Avoidance Costs 255

The 'Hidden' Economy and the Tax Burden 257

Summary 259

Suggested Further Reading $\quad 259$

Exercises $\quad 261$

\section{PART 4 BUDGETS AND BORROWING: FINANCE OF CENTRAL AND LOCAL GOVERNMENT AND THE EUROPEAN COMMUNITY}

13 Central Government Finance 265

The Budget 265

Preparation of the Budget: Administrative Framework 268

The Treasury $\quad 268$

Role of Parliament 270

Audit of Public Expenditure 271

Control and Management of Public Expenditure 272

The New System 276

Private Finance Initiative $\quad 279$

National Lottery $\quad 280$

Summary $\quad 282$

Suggested Further Reading $\quad 283$

Exercises $\quad 284$

14 Public Sector Borrowing 285

National Debt Defined 285

Structure of the National Debt 285

Acquisition of National Debt Holdings 289

National Debt as an Asset and as a Liability 290

Management of the National Debt 291

Origin of the British National Debt 293

Attempts to Repay the National Debt: The Sinking Fund 295

Public Sector Borrowing Requirement (PSBR) 296 
Consequences and the Burden of the National Debt 297

The Internal and External Burden of the National Debt 298

The International Monetary Fund (IMF) 299

The International Bank for Reconstruction and Development 301

$\begin{array}{ll}\text { Summary } & 302\end{array}$

Suggested Further Reading $\quad 302$

$\begin{array}{ll}\text { Exercises } & 304\end{array}$

15 Local Government Finance 305

Organisation and Functions of Local Government 305

$\begin{array}{ll}\text { Features of a Financial System } & 307\end{array}$

Provision of Public Goods and Services $\quad 307$

Pattern and Growth of Local Authorities' Expenditure 311

Reasons for Growth $\quad 314$

Sources of Finance $\quad 315$

$\begin{array}{ll}\text { Rates } & 315\end{array}$

$\begin{array}{ll}\text { The Community Charge } & 319\end{array}$

$\begin{array}{ll}\text { Council Tax } & 320\end{array}$

New Sources of Revenue $\quad 321$

$\begin{array}{ll}\text { Charges and Fees } & 322\end{array}$

The Market Mechanism in the Public Sector $\quad 322$

Pricing Policies of Local Authorities $\quad 323$

The Financial System of Local Authorities $\quad 324$

Changes in Local Authorities' Capital Finance and Borrowing 326

$\begin{array}{ll}\text { Budget and Policies } & 327\end{array}$

$\begin{array}{ll}\text { Summary } & 328\end{array}$

Suggested Further Reading $\quad 329$

$\begin{array}{ll}\text { Exercises } & 330\end{array}$

16 Towards the European Union: Objectives, Policies and Finance of the European Community 331

$\begin{array}{ll}\text { Origins and Transformation } & 331\end{array}$

The European Community and Institutions $\quad 332$

Move Towards the European Union $\quad 334$

The Level and Pattern of Taxation in the Community 334

Social Protection Expenditure and Harmonisation of Measures 335

The Single European Act (1987) 339

The Maastricht Agreement and the Treaty on European Union
and Economic and Monetary Union

Policies of the European Community $\quad 340$

Finance and Budget of the European Community 342

Progress Towards the European Monetary Union and Monetary Policy 345

The European Monetary System, The Exchange Rate Mechanism 345

Relationship Between National Central Governments and Lower-Tier Authorities of the Union 349

The Shape of the New Europe by the Twenty-First Century 351

Summary $\quad 352$ 
Suggested Further Reading 353

Exercises $\quad 354$

\section{PART 5 THE PUBLIC SECTOR OF INDUSTRY AND PUBLIC INVESTMENT}

17 Nationalised Industries and Public Sector Enterprises: An Historical Review

Composition of the Public Sector of Industry 357

The Growth of the Public Sector of Industry 360

Reasons for Nationalisation $\quad 361$

Performance of the Nationalised Industries 363

Organisation and Control of Nationalised Industries 363

Parliamentary Controls $\quad 365$

Planning 366

Financial and Economic Obligations of the Nationalised
Industries

Investment Policies $\quad 369$

Pricing Policies $\quad 370$

$\begin{array}{ll}\text { Borrowing } & 372\end{array}$

Public Dividend Capital (PDC) $\quad 372$

End of an Era 373

Summary 373

Suggested Further Reading $\quad 374$

Exercises $\quad 375$

18 Privatisation 376

Mechanism of Privatisation $\quad 377$

Pricing of State Assets to be Privatised $\quad 379$

The Range of Privatisation Initiatives 389

Consequences of Privatisation in the UK 390

Privatisation in Europe and Elsewhere 391

Privatisation in Former Centrally-Planned Economies 394

$\begin{array}{ll}\text { Summary } & 397\end{array}$

Suggested Further Reading $\quad 398$

Exercises $\quad 400$

19 Investment Appraisal 401

The Purpose of Investment Appraisal 401

Procedure in the Decision-Making Process 401

Pay Back Method of Investment Appraisal 402

Average Rate of Return Method 402

The Discounted Cash Flow (DCF) Technique 403

Outline of Cost-Benefit Analysis 403

Development of Cost-Benefit Analysis $\quad 404$ 
Airport-City Centre Link 405

Problems in Valuation of External Costs and Benefits 406

Limitations of Cost-Benefit Analysis $\quad 407$

Usefulness of Cost-Benefit Analysis $\quad 408$

The Channel Tunnel - A Case Study 408

Summary 411

Suggested Further Reading $\quad 411$

Exercises $\quad 413$

\section{PART 6 MANAGEMENT OF THE ECONOMY}

20 Fiscal Policy to Stabilise the Economy 417

Background to Fiscal Policy 417

Keynesian Prescription $\quad 417$

Monetary Policy: Friedman's Monetarist Prescription 420

$\begin{array}{ll}\text { Inflation and Stagflation } & 421\end{array}$

Prices and Incomes policies $\quad 426$

$\begin{array}{ll}\text { The British Experience } & 429\end{array}$

Summary 431

Suggested Further Reading $\quad 432$

Exercises $\quad 433$

21 Fiscal Policy in Relation to Employment 434

Full Employment 434

Measurement of Unemployment $\quad 436$

Basis for a Policy 438

Frictional Unemployment $\quad 438$

Seasonal Unemployment $\quad 439$

Structural Unemployment $\quad 440$

Regional Unemployment $\quad 441$

European Community Regional Policy $\quad 445$

Cyclical Unemployment 446

Voluntary Unemployment $\quad 447$

Cost of Unemployment $\quad 447$

The 'Job Summit' 448

Future Unemployment Problems 449

Summary $\quad 450$

Suggested Further Reading $\quad 450$

Exercises $\quad 451$

22 Fiscal Policy in Relation to Economic Growth and the Standard of Living 452

Measure of Economic Growth 452

International Comparison $\quad 452$

Factors Influencing Growth 452 
Limits to Economic Growth 454

Economic Welfare and the Standard of Living 454

Elimination of Poverty 454

Fiscal Policy to Increase the Standard of Living 456

Summary $\quad 456$

Suggested Further Reading $\quad 457$

Exercises $\quad 458$

23 Fiscal Policy in Relation to Distribution of Income and Wealth

Objective of Equality $\quad 459$

Causes of Inequality $\quad 459$

Measure of Inequality $\quad 460$

Lorenz Curve $\quad 461$

Formulation of Policy $\quad 462$

Problems of Inadequate Data $\quad 462$

Measures to Redistribute Income and Wealth 465

Inequality at the Regional and International Level 468

Summary $\quad 468$

Suggested Further Reading $\quad 469$

Exercises $\quad 470$

$\begin{array}{ll}\text { Appendices } & 471\end{array}$

$1 \quad$ Calculation of Index Numbers 471

2 Calculation of Changes in the Purchasing Power of Money 474

3 Calculation of Public Revenue, Public Expenditure and

$\begin{array}{ll}\text { Index } & 477\end{array}$ 


\section{List of Tables}

1.1 Money flows in a mixed economy 8

1.2 Adaptation of the mixed economy model 9

1.3 An input-output model (inter-industry transactions) 10

1.4 Simplified input-output model for an economy 13

2.1 Growth of GDP: international comparison 19

2.2 Example of income distribution 21

2.3 National Income of the UK 28

2.4 National Income definitions 31

2.5 Discrepancies in National Income data 31

2.6 National Income: international comparison 35

2.7 National Income, GDP and population 38

2.8 GDP in the UK at constant and current market prices 38

2.9 Consumer price index: international comparison 39

2.10 Complementary indicators of quality of life 40

2.11 Forecasts of economic variables 56

3.1 Equi-marginal returns 61

4.1 Public expenditure on health 80

4.2 Public expenditure on defence 81

5.1 Public expenditure during the two World Wars 91

5.2 Total UK public expenditure by programme 98

6.1 Patterns of taxation: international comparison 131

7.1 Standard rates of income tax in the UK, 1900-95 139

7.2 Progressive tax on income 145

7.3 Income tax and the incentive to work 155

7.4 Effect of tax on overtime 156

8.1 Effect of inflation on small firms 172

8.2 Taxation of profits 173

8.3 Taxation of excess profits 177

8.4 Corporate taxation in Europe 188

8.5 Rates of Corporation Tax in the European Community, $1992 \quad 189$

9.1 Rates of indirect taxation 198

9.2 Taxes on consumption 199

9.3 Indirect taxes as a percentage of total taxes and social security contributions: international comparison 210

10.1 Capital taxes as a source of revenue in the European Community 
10.2 Rates of taxes on capital in Europe 219

10.3 Taxes on the transfer of capital in the UK 223

10.4 Exemptions to taxes on the transfer of capital 226

10.5 Estates passing on death 227

10.6 An example of Succession Duty in Belgium 230

11.1 An example of expenditure tax 236

12.1 Tax level: international comparison 244

12.2 Burden of taxation: international comparison 251

12.3 Income tax on the earned income of a married man:
international comparison of rates

12.4 Hypothetical illustration of the tax burden for Lilliput and Sundra 255

13.1 Types of budgets and budgetary changes 267

14.1 The UK national debt, 1694-1993 293

14.2 Public sector borrowing requirement, 1965-98 297

15.1 The structure of local government in the UK, 1994

15.2 Functions of local authorities 308

$\begin{array}{ll}15.3 \text { Local authorities' expenditure } & 312\end{array}$

15.4 Council Tax valuation bands for dwellings 321

16.1 Some differences in the pattern of taxation in the European Community 335

16.2 Level of taxation of the European Community 335

16.3 Current social protection expenditure as a percentage of GDP 336

16.4 Differences in social security benefits in EC countries 337

17.1 The public sector of industry before privatisation 358

17.2 The size of nationalised industries in the UK at the start of the privatisation programme $\quad 359$

$\begin{array}{ll}18.1 \text { Privatisation: capital gains } & 380\end{array}$

18.2 Return on investment in privatised companies 381

18.3 Privatisation, major sales since $1979 \quad 383$

18.4 Privatisation programmes in selected countries 391

18.5 Share of private enterprise in GDP in Central and

20.1 Hyperinflation in Germany 425

20.2 Hyperinflation in Hungary 426

20.3 Different forms of incomes policy in the UK 427

21.1 Unemployment in the UK, 1900-94 435

21.2 Unemployment: international comparison, 1980-93 436

23.1 Redistribution of wealth 462 
xviii

List of Tables

23.2 Changes in the distribution of incomes: different measurements

23.3 Composition of the net wealth in the personal sector, UK, 1971-92

A1 Government Revenue 


\section{List of Figures}

2.1 Sector model of an economy 23

2.2 GDP of developed and developing countries, 1970-90 36

2.3 The equilibrium level of national income 50

2.4 Trade cycles 51

2.5 Trade cycles: UK and Japan 52

2.6 Internal and external factors in the European
Community affecting trade cycles

2.7 Forecasts of growth in the UK to 2010

5.1 Growth of government expenditure in the UK 100

5.2 Growth of the public sector in the UK 101

5.3 National income, public expenditure and tax revenue in the UK 102

6.1 Direct taxes, indirect taxes and taxes on capital in the UK 132

6.2 An example of Laffer Curve analysis 134

7.1 Revenue from direct taxation 147

7.2 Supply of labour 151

8.1 North Sea oil and gas fields 180

8.2 Tax revenue from North Sea oil 181

9.1 Taxes on consumption 197

10.1 Forms of wealth 214

12.1 Incidence of indirect taxes 247

12.2 Incidence of taxes and benefits 250

13.1 Ministerial responsibilities within HM Treasury 269

13.2 General government expenditure 277

14.1 Distribution of the national debt of the UK 289

14.2 Central government borrowing 294

14.3 Determinants and financing of the PSBR 296

15.1 Local authorities' expenditure and tax revenue 314

15.2 The structure of local authority general funds 325

16.1 The European Community's decision-making process 333

16.2 Social protection expenditure and GDP per head, 1991

18.1 Regional Electricity Companies' authorised areas 387

20.1 Inflation in South America: Argentina 422

20.2 Inflationary spiral $\quad 424$

21.1 UK Assisted Areas 444 
23.1 The Lorenz curve

A1 Index numbers 


\section{Acknowledgements}

I would like to thank Mr Stephen Rutt for all his help and suggestions on how to improve this book, for which I am most grateful. Also, I wish to express my thanks to Keith Povey for his editorial work. I am indebted to Sir Aubrey Trotman-Dickenson, Professor R.E. Groves, Professor of Accountancy at University of Wales, Cardiff and to Mr Martin Corteel for reading an early draft of the manuscript and making helpful comments. My thanks are also due to Mrs Janice Shaw of the Information Technology Centre at the University of Glamorgan for all her work in typing the manuscript onto the computer. I very much appreciated her unfailing patience and efficiency.

The author and publishers wish to thank the Controller of HMSO and the Central Statistical office, United Nations Statistical Division, New York; The Economist (London); Euromonitor (London); Phillips and Drew (United Bank of Switzerland); Policy Studies Institute; Commission of the European Communities; and other copy-right holders for permission to abstract and reproduce some of their statistics.

D.I. TROTMAN-DiCKENSON 


\section{Foreword}

This book on economics of the public sector is concerned with the functions and finance of central government, local authorities and the public sector of industry within the framework of a national economy. The subject is of primary importance to any study of society in which people live.

The theory and practice of public finance presented in this book cover public expenditure, taxation and the national debt. Fiscal policy, with its economic, social and political objectives, is discussed and viewed in relation to monetary policy and prices and incomes policy. International comparisons are made and points are illustrated by examples from the British economy, European Community and other countries.

It is hoped that Economics of the Public Sector will serve as a source of information to the general reader, and as a textbook for students in their final year at school and on various courses at institutions of higher education. The bibliography at the end of each chapter is intended to give guidance on further reading. The various publications and books listed deal with topics at different levels and provide a basis for continuation of the study of public finance.

The material in Economics of the Public Sector is presented in such a way as to facilitate self-study for part-time students. Exercises at the end of each chapter can be used as a basis for revision.

The subject matter of the book is suitable for use for General Certificate of Secondary Education examinations in Economics as the syllabuses of the examining Boards cover public finance. The book is also appropriate for Business and Technician Education Council (BTEC) and degree courses and also for those leading to qualifications of professional bodies such as the Institute of Public Finance and Accountancy and the Institute of Chartered Administrators.

A large number of tables and diagrams have been provided so as to relate the theory to the real world. Students are advised to examine the economic data and to consider its implications.

Every effort has been made to provide the latest statistics available. In some cases, particularly with the United Nations data, there is a considerable gap between the date of publication and the year to which the figures refer. Nevertheless, even if the data becomes superseded by more recent information, the figures are still of value in indicating magnitudes of 
money flows and the dimension of economic problems. Some historical background is also helpful in the study of public sector economics. To understand the present and plan for the future, we need to know the past. 